\title{
Factors related to food involvement in the adult population
}

\author{
Fatores relacionados ao envolvimento com \\ alimentação da população adulta
}

Bárbara de ALENCAR ${ }^{1}$

Natacha TORAL ${ }^{1}$

Elisabetta RECINE ${ }^{1}$

Anelise RIZZOLO ${ }^{1}$

\section{Objective}

This study aimed to investigate aspects associated with food involvement and to ascertain whether individuals with higher food involvement consume larger amounts of fruits and vegetables.

\section{Methods}

This cross-sectional, analytical study was conducted with 301 adults (19-59 years old) from the Federal District, Brazil. Sample size calculation was based on numbers from the Brazilian Demographic Census and on consumption data for fruits and vegetables obtained from the Surveillance of Risk and Protective Factors for Chronic Diseases by Telephone Interviews survey. Data were collected in October of 2012. The questionnaire comprised 28 questions and included socio-demographic variables, reported fruit and vegetable consumption, and an adapted food involvement scale. Data were analyzed using Statistical Package for the Social Sciences software. Descriptive and comparative analyses were performed to determine population characteristics.

\section{Results}

Women and older individuals displayed a higher degree of food involvement than did men and younger individuals $(p<0.001)$. Among the factors included in food involvement, the highest influence was attributed to satisfaction in preparing food (cooking), pre-preparation of food, and pleasure in cooking for other people $(p<0.001)$.

\section{Conclusion}

The results presented here suggest that food involvement can be stimulated through innovative strategies of communication that go beyond the biological arguments and focus on the cultural expression of the elements of socialization, whose relationship with eating is well established.

Keywords: Food consumption. Food planning. Food preferences.

\footnotetext{
1 Universidade de Brasília, Faculdade de Ciências da Saúde, Departamento de Nutrição. Campus Universitário Darcy Ribeiro, 70910-900, Brasília, DF, Brasil. Correspondência para/Correspondence to: B ALENCAR. E-mail: <btalencar@gmail.com>.
} 


\section{R E S U M O}

\section{Objetivo}

Investigar os aspectos associados ao envolvimento com alimentação e verificar se os indivíduos que apresentam um maior envolvimento com alimentação consomem maiores quantidades de frutas e hortaliças.

\section{Métodos}

Estudo analítico transversal conduzido com 301 adultos (19-59 anos) do Distrito Federal. O cálculo amostral foi baseado no quantitativo fornecido pelo Censo Demográfico Brasileiro e em dados de consumo referido de frutas e hortaliças, de acordo com dados da pesquisa Vigilância de Fatores de Risco e Proteção para Doenças Crônicas por Inquérito Telefônico. A coleta de dados ocorreu em outubro de 2012. O questionário, composto por 28 questões abrangeo as variáveis sócio-demográficas, consumo referido de frutas e hortaliças e uma escala de envolvimento com alimentação, adaptada. Os dados foram analisados utilizando o software Statistical Package for the Social Sciences. Análises descritivas e comparativas foram realizadas para verificar as caracteristicas da população.

\section{Resultados}

Mulheres e indivíduos mais velhos apresentaram um grau de envolvimento com a alimentação maior que homens e pessoas mais jovens $(p<0,001)$. Dentre os fatores que compõem o envolvimento com alimentação tiveram maior influência os relacionados à satisfação em preparar de alimentos (cozinhar), ao pré-preparo de alimentos e ao prazer de cozinhar para outras pessoas $(p<0,001)$.

\section{Conclusão}

Os resultados apresentados sugerem que o envolvimento com alimentação pode ser estimulado por meio de estratégias de comunicação inovadoras, que ultrapassem o sentido biológico e se concentrem na expressão cultural sobre os elementos de socialização, reconhecidamente relacionados à alimentação.

Palavras-chave: Consumo de alimentos. Planejamento alimentar. Preferências alimentares.

\section{INTRODUCTION}

The prevalence of overweight and obesity in the adult population has become a serious public health problem worldwide. In Brazil, the more recent Surveillance of Risk and Protective Factors for Chronic Diseases by Telephone Interviews survey showed that $17.9 \%$ of the population was obese with $50.8 \%$ overweight ${ }^{1}$. Different aspects contribute to this scenario, especially eating practices favoring a high consumption of ultra-processed food (sandwich cookies, processed snack foods, soft drinks, and instant noodles, among others) with high energy density and the ingestion of drinks with added sugar 2,3 .

According to the National Policy on Food and Nutrition ${ }^{4}$, a healthy diet must take into account biological, cultural, social, and environmental sustainability aspects. Furthermore, it must provide quality and balance, respect the characteristics of each stage of life, and conform to individual habits and needs.
According to the World Health Organization, the adoption of healthy eating habits includes daily intake of at least $400 \mathrm{~g}$ of fruits and vegetables ${ }^{5}$, or equivalent to five portions daily ${ }^{6}$. These foods, which are low in energy density and rich in fiber, help protect against chronic diseases and overweight?

The involvement of an individual with his or her own food seems to contribute importantly to the adoption of healthy eating habits ${ }^{8-10}$. Bell \& Marshall ${ }^{9}$ define food involvement as the level of importance of this theme in the life of a person. They showed that the involvement of people with their eating is typified by an investment of time and effort before and during the choice of food and preparation method. It is believed that food involvement varies with gender, with the eating experiences during the course of life (including the family attitude toward food, such as frequency of meals, rituals, and symbolism of eating and of food), and with the interest in aspects related to eating. It has also been suggested that food 
involvement may affect individual choices concerning food purchase and preparation.

National and international studies show the influence of different factors on how individuals make their food choices, such as preparation time, the taste of the food, and durability ${ }^{11-13}$. Aspects related to the environment in which a person is inserted, such as access to point-of-purchase and cost of food, may also foster or make it harder to acquire healthy eating habits ${ }^{14,15}$.

Alves ${ }^{16}$ indicated that, among the greatest reported challenges to healthy eating are a lack of time for shopping and food preparation, cost of food, and lack of expert advice.

Based on these aspects, food involvement was investigated among adults from the Federal District, Brazil, to determine its relationship with population characteristics and with their consumption of fruits and vegetables. It was also asked if greater food involvement was associated with higher consumption of fruits and vegetables by this population.

\section{METHODS}

This was a cross-sectional, analytical study performed with the adult population (aged 19-59 years) of the Federal District, including its 19 Administrative Regions, totaling 301 interviewed subjects. Sample size calculation was based on the population characteristics reported in the 2010 Brazilian Demographic Census ${ }^{17}$ and on reported consumption data for fruits and vegetables ${ }^{18}$. According to the 2010 Census, there were 1,543,309 individuals aged 19-59 years old residing in the Federal District. Thus, considering a $24.8 \%$ prevalence of daily fruit and vegetable consumption, a confidence level of $95.0 \%$, and a sample loss of $5.0 \%$, we calculated a sample size of 286 individuals to guarantee sample representativeness for each administrative region.

Data were collected in October of 2012 by trained interviewers. Individuals were approached randomly in bus stations, city squares, commercial centers, and recreational places in the different administrative regions of the Federal District. Interviews were performed only with residents in the administrative region in which data collection was being performed who were 19 to 59 years old, agreed to answer the survey, and signed the Informed Consent Form. In case of refusal or inability to participate, another person was approached. To maintain a gender proportion similar to that of the population, men and women were interviewed alternately. At the end, the person interviewed was given a leaflet on healthy eating. The average duration of the interviews was 13 minutes, and 301 interviews were performed. All interviews were included in the database.

Individuals who had difficulty understanding, speaking, or listening did not participate in the sampling as these factors could prevent answering the questions.

The questionnaire comprised 28 questions, including socio-demographic variables, reported consumption of fruits and vegetables, and a scale of factors related to food involvement.

Socio-demographic variables researched were gender, age (in years), level of education, and income (assessed by the ownership of durable goods), pursuant to the Critério de Classificação Econômica Brasil (Brazil Income Classification Criteria ${ }^{19}$ ). According to these criteria, individuals are divided into six classes based on the monthly family income, ranging from $\mathrm{R} \$ 776.00$ for the lowest class to $R \$ 14,366.00$ for the highest.

Data relating to food involvement were obtained with an adaptation of the Food Involvement Scale developed in 2002 by Bell \& Marshall ${ }^{9}$. The original version includes 12 items with a Likert scale ranging from (1) "completely disagree" to (7) "completely agree". In this study, the interval between the possible answers was reduced from 7 to 5 points to improve understanding by the participants. To obtain the result, the score was calculated by the sum of the answers. The higher the score, the greater the food involvement of the person. The highest 
possible score was 60 points. The items included in the scale are described in Table 1.

To apply the scale to the local population, the original version was translated and the language adapted. The procedure adopted was to a) translate the original instrument from English to Portuguese, b) back-translate the instrument from Portuguese to English, and c) technically review the content.

Interviewees were also asked about the daily frequency of fruit and vegetable consumption as well as the amount consumed in portions. Interviewees were verbally informed about the concept of portions of fruits and vegetables, the same as that adopted by the Food Guide for the Brazilian Population ${ }^{6}$ current at the time of the survey: a portion of vegetables is the equivalent to a saucer (or a cup) of raw vegetables, excluding potatoes and other starchy foods. For fruits, a portion is equivalent to an average banana unit, a small apple unit, an average slice of pineapple, a small slice of papaya, or a small bunch of grapes ${ }^{6}$. Consumption reported by the interviewees was rated as either adequate (five or more portions a day) or inadequate (less than five portions a day).

Data were analyzed using the statistical software Statistical Package for Social Sciences (SPSS) version 20.0, in Portuguese. Descriptive and comparative analyses were performed to ascertain the population characteristics.
The descriptive results were used to characterize the sample. They were obtained and analyzed due to their relationship with food involvement, which was demonstrated in previous studies testifying to the relationship between food involvement and variables such as gender, age, and income level $\left.\right|^{9,10}$.

Multiple regression was used to determine the internal contribution of each factor, related to the scale of food involvement, with the final involvement result. We opted to make this analysis in order to determine the contribution of different behavioral factors to the degree of food involvement.

Normality of the data was verified by the Shapiro-Wilk test with a $5 \%$ significance level. The standard multiple regression method was used to identify the variables (gender, age, income, or education) that are better predictors of food involvement.

We also compared the average food involvement with the consumption of fruits and vegetables.

This project was approved by the Research Ethics Committee of the Faculty of Health Sciences, University of Brasilia (CEP-FS/UnB), Protocol number 057/10.

\section{RES U LT S}

Approximately a third of those interviewed were young people between 19 and 29 years old,

Table 1. Contributions of items from the translated Food Involvement Scale to the final score.

\begin{tabular}{lc}
\hline Translated Food Involvement Scale & $R(p<0.001)$ \\
\hline 1. I usually think about my diet. & 0.542 \\
2. I like preparing food (cooking). & 0.656 \\
3. At mealtime, I usually talk to others about what I'm eating or what they intend to eat. & 0.635 \\
4. Regarding the decisions I have to make on a daily basis, those related to food are the most important. & 0.385 \\
5. When traveling, I often worry about how I will eat. & 0.365 \\
6. After making my meals, I usually clean up the preparation space. & 0.390 \\
7. Cooking for other people and for myself something quite pleasurable, that I love to do. & 0.625 \\
8. I tend/like to talk about the taste of meals at home and outside the home. & 0.465 \\
9. Usually I tend/like to select, wash, peel, chop the food. & 0.652 \\
10.I usually am responsible for choosing and buying food in my house. & 0.515 \\
11.I usually wash the dishes used to prepare and consume meals. & 0.395 \\
12.I often worry about the organization of the local where I perform my meals. & 0.425 \\
\hline
\end{tabular}


and $50.2 \%$ were women. Most individuals had an average monthly income estimated at $R \$ 2,327.00$ (31.6\%) followed by $R \$ 1,391.00$ (21.3\% of those interviewed). Most of the individuals (70.2\%) reported having completed secondary education (Table 2 ).

According to the results from the Food Involvement Scale, participants showed an average food involvement of $44.08 \pm 8.69$. The lowest score was 20 points $(0.3 \%, n=1)$, and the highest was $60(2.6 \%, n=8)$.

Women displayed a significantly higher degree of food involvement than did men $(46.96 \pm 7.91$ versus $41.17 \pm 8.50, p<0.001)$. Moreover, older individuals (50-59 years old) also displayed higher average food involvement than did younger ones. Young adults (19-29 years old) presented the lowest average involvement $(40.95 \pm 8.77)$ (Table 3).

No significant difference was observed among the groups regarding income or level of education ( $p>0.05$ ).

Table 2. Distribution of number and percent interviewed by age group, educational level, and income class. Brasilia (DF), Brazil, 2012.

\begin{tabular}{lcc}
\hline \multirow{2}{*}{ Groups } & \multicolumn{2}{c}{ Distribuition } \\
\cline { 2 - 3 } & $\mathrm{n}$ & $\%$ \\
\hline Age (years) & 94 & 31.2 \\
$19-29$ & 83 & 27.6 \\
$30-39$ & 64 & 21.3 \\
$40-49$ & 60 & 19.9 \\
$50-59$ & 301 & 100.0 \\
\hline Total & & \\
\hline Education & 87 & 30.0 \\
Complete primary & 121 & 40.2 \\
Complete secondary & 93 & 30.8 \\
Complete higher & 301 & 100.0 \\
\hline Total & & \\
\hline Income class & 8 & 2.7 \\
A1 & 25 & 8.3 \\
A2 & 43 & 14.3 \\
B1 & 95 & 31.6 \\
B2 & 64 & 21.3 \\
C1 & 46 & 15.3 \\
C2 & 20 & 6.5 \\
DE & 301 & 100.0 \\
\hline Total & & \\
\hline & & \\
\hline
\end{tabular}

Table 3. Average food involvement according to age group. Brasilia (DF), Brazil, 2012.

\begin{tabular}{lcc}
\hline \multirow{2}{*}{ Age (years) } & \multicolumn{2}{c}{ Food involvement } \\
\cline { 2 - 3 } & $\mathrm{M}$ & SD $^{*}$ \\
\hline $19-29$ & 40.95 & 8.77 \\
$30-39$ & 45.16 & 8.46 \\
$40-49$ & 45.47 & 7.92 \\
$50-59$ & 46.00 & 8.52 \\
\hline
\end{tabular}

Note: ${ }^{*} p \leq 0.001$.

M: Mean; SD: Standard Deviation.

Testing the contribution of the sociodemographic variables to food involvement, standard multiple regression indicated that only the gender and age variables were correlated to the food involvement variable $\left(r_{\text {gender }}=0.235\right.$, $\left.p<0.01 ; r_{\text {age }}=0.235, p<0.01\right)$. Income and level of education variables showed no correlation with food involvement $\left(r_{\text {income }}=0.136, p=0.110\right.$; $\left.r_{\text {education }}=-0.178, p=0.08\right)$.

Regarding consumption of fruits and vegetables, most of those interviewed (93.4\%, $n=281$ ) reported consuming less than five portions of fruits and vegetables per day. Only 6.6\% $(n=20)$ reported consuming fruits and vegetables five or more times a day. It is noteworthy that the average food involvement of these individuals was higher than for those who reported a consumption of less than four times a day $(p<0.001)$ (Table 4).

Multiple regression analysis to test the contribution of each item to the scale showed that the items with the highest correlation with the final score were those related to satisfaction in preparing food (cooking) $(R=0.656, p<0.001)$, pre-preparation of food $(R=0.652, p<0.001)$, and pleasure in cooking for other people $(R=0.625$, $p<0.001)$. The item with the least correlation was related to worrying about food during trips $(R=0.365, p<0.001)$ (Table 1).

\section{DISCUSSION}

Data from the latest District Survey by Pesquisa Distrital por Amostra de Domicílios 
Table 4. Frequency distribution of daily fruit and vegetable consumption and average food involvement. Brasilia (DF), Brazil, 2012.

\begin{tabular}{|c|c|c|c|c|}
\hline \multirow{2}{*}{ Fruit and vegetable consumption (Daily) } & \multicolumn{2}{|c|}{ Distribution } & \multicolumn{2}{|c|}{ Food involvement } \\
\hline & $\mathrm{n}$ & $\%$ & $\mathrm{M}$ & $\mathrm{SD}^{*}$ \\
\hline Adequate (5 or more portions) & 20 & 6.6 & 46.58 & 8.92 \\
\hline Inadequate (4 portions or less) & 281 & 93.4 & 41.03 & 7.41 \\
\hline
\end{tabular}

Note: ${ }^{*} p \leq 0.001$.

M: Mean; SD: Standard Deviation.

(PDAD, Household Sampling), a socio-demographic survey in the Federal District, indicate that the majority of the population in the Federal District is female (51.98\%), and $65.69 \%$ of the population is between 15 and 59 years old. The same survey indicates that the average monthly income for the Federal District is around $R \$ 1,489.57$. As for the level of education, $4.07 \%$ of the Federal District population completed primary education, and $20.21 \%$ completed secondary education followed by those who completed higher education, including masters and doctoral degrees, at $17.27 \%^{20}$. We conclude that the sample profile in this study was very similar to that found in the PDAD regarding gender, income, and educational level distributions.

Only $12.6 \%$ of participants reported consuming five or more portions of fruits and vegetables daily. These data disagree with those in the Surveillance of Risk and Protection Factors for Chronic Diseases by Telephone Interviews ${ }^{1}$ survey, which indicates that $29.7 \%$ of adults in the Federal District consumed five or more portions of fruits and vegetables daily. The difference may be explained by different approaches used in the interviews; the present one was conducted in person with the notion of portion being explained to the interviewee, possibly resulting in better understanding of the question, while the aforementioned survey was done by telephone.

The collected data point to a greater degree of food involvement by women and by older individuals (50-59 years old). Studies in different populations also identified this relationship with factors such as gender and age, demonstrating that women and older persons show greater food involvement ${ }^{9,10}$. In their works, Bell \& Marshall ${ }^{9}$ showed that women have greater food involvement when compared to men.

These differences of food involvement between the male and female genders are determined by social, psychological, and cultural reasons ${ }^{11,21}$. One essential aspect normally attributed to women is the role of taking care of the family and meals. The social and cultural roles performed by women result in greater concern regarding eating for both health and aesthetic reasons and for both themselves their family members ${ }^{22,23}$. The greater involvement of older individuals with food may be explained by concerns related to health that are associated with the vulnerability related to aging. Additionally, acquired experience often predisposes an individual to pay more attention to and concern themselves with the choices made throughout their lives ${ }^{9}$.

National studies investigating consumption of fruits and vegetables by the Brazilian population confirm that women and older people consume a larger amount of fruits and vegetables compared to other groups (men and young people) $)^{24,25}$.

Factors such as income and level of education were also reported by both the authors of the Food Involvement Scale ${ }^{9}$ and other researchers in the same period as factors related to food involvement ${ }^{9,26-28}$. However, in this study, no association was found between these factors.

Participants who reported a higher consumption of fruits and vegetables (five or more 
daily portions) were also those with the highest average food involvement. These results agree with previous studies indicating that individuals with a higher degree of food involvement are more likely to choose healthier foods $s^{9,10}$.

Despite the data collected in this study, it is not possible to state that higher food involvement will have a direct impact on the consumption of fruits and vegetables as this was a cross-sectional study. However, our results do point to a positive relationship between fruit and vegetable consumption and food involvement. This analysis suggests the need for other studies to improve understanding of this association in order to develop new actions to promote this consumption in the context of proper and healthy eating.

Food involvement includes different aspects of eating. As seen above, aspects related to food preparation (cooking), pre-preparation, and pleasure in cooking for other people had a higher influence in the final score.

This result is particularly important in the context of the recent publication of the Food Guide for the Brazilian Population ${ }^{3}$. That material emphasizes that one of the barriers to proper and healthy eating is precisely the lack of what was called "culinary skills", and two of the steps toward proper and healthy eating are "developing, practicing, and sharing culinary skills" and "eating regularly and mindfully in appropriate environments and, as often as possible, in the company of other people".

The contribution of the scale item "preparing food for others" demonstrates the importance of the social, relational dimension and of the care act involved in a meal. Savarin ${ }^{29}$ emphasizes the preliminary care taken with meal preparation, choice of place, and gathering of guests as essential aspects of the pleasure of eating.

Cooking involves a series of techniques culturally conceived to convert in natura products into food. For Pollan ${ }^{30}$, the act of cooking is one of the most interesting and gratifying collective actions that human beings have created, since sharing meals contributes to the preservation of culinary practices, recovering cultural values that are being lost in current society.

Furthermore, the importance to those interviewed of aspects such as preparation and pre-preparation of food and cooking highlighted the role of the act of eating for people. Eating is an essential part of human life, surpassing the biological dimension and involving dimensions such as pleasure, sharing, sociability, and social life.

Thus, actions that promote higher food involvement need to be stimulated through strategies that encompass the five dimensions of nourishment cited by Castro et al. ${ }^{31}$ human rights and biological, sociocultural, economic, and environmental dimensions (ways of making, marketing, and consuming food).

The contribution of this study was investigating food involvement as one of the determinant factors of food consumption, considering aspects ranging from the imagined meaning of food through stages of selection, purchase, and preparation of meals. Despite the limitation of the scale adapted to Portuguese not being validated, the translation attempted to adjust the language to prevent possible errors of interpretation from the studied population, and a positive relationship was observed between food involvement and fruit and vegetable consumption by the population, as expected.

\section{CONCLUSION}

This study indicates that women and older individuals have higher food involvement than men and younger individuals. Those with the highest fruit and vegetable consumption are also those with the highest food involvement, and the main contributing factors are aspects related to the satisfaction in preparing food. 
This highlights the importance of developing strategies that promote a higher involvement of individuals and groups with their food, such as promoting skills that facilitate the choice and preparation of food and that do not reduce eating to a biological process capable of preventing or causing diseases, centering on a group of medicalizing measures, and reducing eating to a simple physical need of nutrient ingestion. Such perspectives draw nutritionists and health professionals away from a perspective of understanding food and nutritional issues inserted in a nourishment system multi-determined by political, social, cultural, ethical, and economic relationships. Adoption of a communication strategy that promotes the involvement of individuals with their food must have a practical and everyday message that communicates with the anthropological and cultural dimensions and the socializing elements that govern eating.

\section{COLLABORATORS}

BA TEIXEIRA prepared the projetc, data collection and analysis, and discussion. N TORAL and E RECINE analyzed data, review, and elaboration of discussion. A RIZZOLO collaborated in the analysis, and discussion.

\section{REFERENCES}

1. Brasil. Ministério da Saúde. Secretaria de Vigilância em Saúde. Vigitel Brasil 2014: Vigilância de Fatores de Risco e Proteção para Doenças Crônicas por Inquérito Telefônico [apresentação]. Brasília: Ministério da Saúde; 2014 [acesso 2015 out 5]. Disponível em: http://portalsaude.saude.gov.br/ images/ pdf/2015/abril/15/PPT-Vigitel-2014-pdf

2. Souza AM, Pereira AR, Yokoo EM, Levy RB, Sichieri R. Most consumed foods in Brazil: National Dietary Survey 2008-2009. Rev Saúde Pública. 2013; 47(1):191S-9S. http://dx.doi.org/10.1590/S0034-8 9102013000700005

3. Brasil. Ministério da Saúde. Secretaria de Atenção à Saúde. Guia alimentar para a população brasileira. $2^{a}$ ed. Brasília: Ministério da Saúde; 2014 [acesso 2015 set 28]. Disponível em: http://189.28.128.10 0/dab/docs/portaldab/publicacoes/guia_alimentar_ populacao_brasileira.pdf

4. Brasil. Ministério da Saúde. Secretaria de Atenção à Saúde. Política Nacional de Alimentação e Nutrição. Série B. Textos Básicos de Saúde. Brasília: Ministério da Saúde; 2012 [acesso 2013 janeiro 10]. Disponível em: http://dab.saude.gov.br/portaldab/ biblioteca. .php? conteudo=publicacoes/pnan

5. World Health Organization. Diet, nutrition and prevention of chronic diseases: Report of the joint WHO/FAO expert consultation. WHO Technical Report Series, n 916. Geneva: WHO; 2003 [cited 2015 May 4]. Available from: http://www.who.int/diet physicalactivity/publications/trs916/download/en/

6. Brasil. Ministério da Saúde. Secretaria de Assistência à Saúde. Guia alimentar para a população brasileira: promovendo a alimentação saudável. Brasília: Ministério da Saúde; 2005 [acesso 2012 mar 7]. Disponível em: http://bvsms.saude.gov.br/bvs/ publicacoes/guia_alimentar_populacao_brasileira_ 2008.pdf

7. Wynn E, Krieg MA, Lanham-New SA, Burckharrdt P. Postgraduate symposium. Positive influence of nutritional alkalinity on bone health. Proc Nutr Soc. 2010; 69(1):166-73. http://dx.doi.org/10.1017/S0 02966510999173X

8. Rozin P, Fischler C, Imada S, Sarubin A, Wrzesniewski A. Attitudes to food and the role of food in life in the USA, Japan, Flemish Belgium and France: Possible implications for the diet-health debate. Appetite. 1999; 33(2):163-80. http://dx.doi.org/10. 1006/ appe.1999.0244

9. Bell R, Marshall DW. The construct of food involvement in research: Scale development and validation. Appetite. 2003; 40(3):235-44. http://dx.doi.org/ 10.1016/50195-6663(03)00009-6

10. Barker M, Lawrence W, Woadden J, Crozier SR, Skinner TC. Women of lower educational attainment have lower food involvement and eat less fruit and vegetables. Appetite. 2008; 50(2-3): 464-8. http://dx.doi.org/10.1016/S0195-6663(03) 00009-6

11. Canesqui AM, Garcia RWD. Antropologia e nutrição: um diálogo possível. Rio de Janeiro: Fiocruz; 2005.

12. Chambers $S$. The influence of age and gender on food choice: A focus group exploration. In J Cons Stud. 2008; 32(4):356-65. http://dx.doi.org/10.111 1/j.1470-6431.2007.00642.x

13. Honkanen P, Frewer L. Russian consumers' motives for food choice. Appetite. 2009; 52(2):363-71. http://dx.doi.org/10.1016/j.appet.2008.11.009 
14. Swinburn B, Egger G, Raza F. Dissecting obesogenic environments: The development and application of a framework for identifying and prioritizing environmental interventions for obesity. Prev Med. 1999; 29(6):563-70. http://dx.doi.org/10.1006/ pmed.1999.0585

15. Souza RS, Arbage AP, Silva A, Baumhardt E, Lisboa RS. Comportamento da compra do consumidores de frutas, legumes e verduras (FVL) na região central do Rio Grande do Sul. Ciênc Rural. 2008; 38(2):511-7.

16. Alves HFC. Atitudes face à alimentação e critérios de escolha individual de produtos alimentares [mestrado]. Porto: Universidade do Porto; 2007.

17. Instituto Brasileiro de Geografia e Estatística. Censo Demográfico. Brasília: IBGE; 2010 [acesso 2012 fev 10]. Disponível em: http://www.ibge.gov.br/home/ estatistica/populacao/censo2010/default.shtm

18. Brasil. Ministério da Saúde. Secretaria de Vigilância em Saúde. Vigitel Brasil 2011: vigilância de fatores de risco e proteção para doenças crônicas por inquérito telefônico [apresentação]. Brasília: Ministério da Saúde; 2012 [acesso 2012 mar 7]. Disponível em: http://portalsaude.saude.gov.br/portal saude/arquivos/pdf/2012/Abr/10/vigitel_100412. pdf

19. Associação Brasileira de Empresas de Pesquisa. Critério de classificação econômica Brasil. São Paulo: ABEP; 2013 [acesso 2012 jun 16]. Disponível em: http://www.abep.org/criterioBrasil.aspx

20. Brasília. Governo do Distrito Federal. Secretaria de Estado Planejamento e Orçamento do Distrito Federal. Pesquisa distrital por amostra de domicílios (PDAD). Brasília: Governo do Distrito Federal; 2014.

21. Gedrich K. Determinants of nutritional behavior: A multitude of levers for successful intervention? Appetite. 2003; 41(1):231-38. http://dx.doi.org/10. 1016/j.appet.2003.08.005

22. Jomori MM. Escolha alimentar do commensal de um restaurant por peso [mestrado]. Florianópilis: Universidade Federal de Santa Catarina; 2006.
23. Jomori MK, Proença RPC, Calvo MCM. Escolha alimentar: A questão de gênero no contexto da alimentação fora de casa. Cad Espaço Feminino. 2008; 19(1):369-84.

24. Jaime PC, Monteiro C. Fruit and vegetable intake by Brazilian adults, 2003. Cad Saúde Pública. 2005; 21(1):S19-S24. http://dx.doi.org/10.1590/S0102-3 $11 \times 2005000700003$

25. Neutzling MB, Rombaldi AJ, Azevedo MR, Hallal $P C$. Fatores associados ao consumo de frutas, legumes e verduras em adultos de uma cidade no sul do Brasil. Cad Saúde Pública. 2009; 25(11): 2365-74. http://dx.doi.org/10.1590/S0102-311X20090011 00007

26. Eertmans A, Victoir A, Vansant G, Van den Bergh O. Food-related personality traits, food choice motives and food intake. Food Qual Prefer. 2005; 16(8):714-26. http://dx.doi.org/10.1016/j.food qual.2005.04.007

27. Hu Y. An exploration relationships between festival expenditures, motivations, and food involvement among food festival visitors [Master thesis]. Ontario: University of Waterloo; 2010.

28. Soontrunnarudrungsri $A$. Development and validation of screening tools for classification consumers of food products based on eating healthy criteria. Manhattan: Kansas State University; 2011.

29. Savarin B. A fisiologia do gosto. São Paulo: Companhia das Letras; 1999.

30 Pollan M. Cozinhar: uma história natural de transformação. Rio de Janeiro: Intríseca; 2013.

31. Castro IRR, Castro LMC, Gugelmim. Ações educativas, programas e políticas envolvidos nas mudanças alimentares. In: Castro IRR. Desafios e perspectivas para a promoção da alimentação adequada e saudável no Brasil. Cad Saúde Pública. 2012; 31(1):7-9. http://dx.doi.org/10.1590/0102-311XPE 010115

Received: June 1, 2015

Final version: October 13, 2015

Approved: February 23, 2016 
